\title{
IMPACT OF INNOVATIONS ON GDP DYNAMICS
}

The aim of this paper is to study the impact of innovations on GDP dynamics in 30 countries of different level of development. The highest level of correlation has been indicated between the GDP dynamics and the following innovation variables: trademark applications, patent applications, high-technology exports, information and communication technology goods imports and renewable energy consumption. Analyzing the relationship between GDP dynamics and innovation variables in Ukraine rather weak association of innovations and economic development can be observed in most cases.

Keywords: impact, correlation, relationship, GDP dynamics, economic growth, innovation.

DOI: $10.21272 / \mathrm{mmi} .2017 .2-14$

Introduction. Innovation plays a remarkable role in driving economic growth and lead to an improvement in the standard of living in many countries. Growth theory insist on the role of innovation in stimulating economic growth along with other factors like capital and human resources. Innovationdriven economic growth experience of developed countries can become the valuable lesson for many post-soviet countries that have been looking for a new driver of economic development.

Analysis of recent researches and publications. Scientists have been researching factors of economic growth for years. The researchers have found a strong positive role of innovations for economic growth. Thus, Dirk Czarnitzki and Otto Toivanen [1] established a link between investments in economic growth and investments in R\&D (research and development). They found that public R\&D grants stimulate private investments in the countries studied. Dirk Czarnitzki and Otto Toivanen [1] stated that various implications of the Schumpeterian model had found empirical support. Such empirical findings have implications on the structure government support to private sector R\&D. They [1] witnessed that most OECD countries and an increasing number of emerging economies such as India use R\&D subsidies and R\&D tax incentives. Ukrainian scientist Lyubov Fedorova [2] also states that investments in technologic development are considered by developed countries (USA, Japan, EUcountries) and by growing economies of China, India, Brazil as the key anti-crisis measures. Nevertheless, the post-socialist countries budget policy analysis leads to the assumption that slow economic growth, that is typical for many of these states, might result from insufficient state budget support of innovations. Thus, when analyzing the funding of innovation activity in Ukraine Olena Strelina [3] concludes that in 2000-2012 own funds of the enterprises were used for implementing innovations as the main financial source; however the state budget support was rather low.

Research paper of Birgitte Gregersen and Björn Johnson [4], who are also concerned about the role of innovation in economic development, gives an overview of various approaches to how innovations affect economic growth: from standard macroeconomic equilibrium theory, growth accounting, new growth theories, catching-up theories, evolutionary theories based on theories of techno-economic paradigms and co-evolution to a systems of innovation approach. The researchers insist that for policy makers, who try to stimulate growth by supporting innovations, the focus should be on designing and implementing institutional changes that continuously supports technical and organizational learning and innovation.

Research paper of Nathan Rosenberg [5] illustrates why technological innovation is considered as a major force in economic growth and focuses on some of the most distinctive features of innovation in the 
highly industrialized economies of the OECD area. When analyzing innovation experience of EUcountries Valerij Heyets and Volodymyr Semynozhenko [6] state that the knowledge-based industries and services have become the basis of economic development of European Union.

While V.N. Heyets ta V.P. Semynozhenko studied EU countries the research of Roman Gurbiel [7] was focused on the experiences of Central and Eastern European Countries (with special emphasis on Poland, the Czech Republic and Slovak Republic) in innovation and technology transfer policies during economic transition and the challenges faced during EU enlargement. He concludes that innovation and technology transfer are the key drivers of economic growth in today's world economy. He found that there is a high correlation between the intensity of technology transfer and a country's innovation capabilities. Roman Gurbiel [7] notes that the policy of economic development could be broadly characterized as moving from import substitution to export promotion. According to Roman Gurbiel state policy enabled to acquire basic technologies mainly through import. After that once acquired technologies were further developed using local R\&D capabilities, based on broad linkages between state and private research institutes. Analyzing Central and Eastern European economies he observes that despite some progress made in recent years Central and Eastern European countries still lag behind many of their European Union neighbors. Roman Gurbiel [7] conclude that because of lacking of effective technology transfer from R\&D sector to industry, import and foreign direct investments are the main channels of technology transfer in transition countries. It should be noted that the changes implemented in transition countries can not be truly considered as innovations, because these ideas and technologies derive from developed countries. Characterizing innovations of that kind Sergii Illiashenko [8] uses the term "quasi-innovation" and argues that these changes can be considered innovative only within the countries implementing these technologies and ideas. Shqipe Gerguri and Veland Ramadani [9] highlight several core conditions that enable innovation and encourage economic growth: strong standards and effective enforcement of intellectual property protection, vigorous competition and contestable markets, a strong and sustainable fundamental research and development infrastructure, encouraging information and technology communication developments, a strong emphasis on education at all levels, etc. The study performed by Changtao Wang [10] uses patent and trademark statistics as innovation proxies to examine the long-run relationship between innovation and output in countries with a long-established system of intellectual property rights. The findings provide evidence that innovation may no longer be playing a positive role in driving economic growth. Post-World-War-ll evidence for countries with extensive measured innovation (e.g. the US) shows that innovation had non-positive effects on economic growth in most countries studied [10].

There is no essential impact of innovations on economic development in Ukraine. In the last 15 years the fraction of the innovation enterprises didn't exceed $18 \%$ of the total amount of Ukrainian enterprises, and in 2015 it was equal to 17,3\% [11]. According to European Innovation Scoreboard Ukraine is a "Modest Innovator" which SII-Summary Innovation Index equals 0.206 . This is a half of the average index of EU-countries (0.544) [12]. Nowadays Ukraine takes the first steps on the way to innovation strategy of economic development of the country. There are innovation hubs, science and study hubs, innovation business incubators, innovation and technology transfer hubs, intellectual property commercialization hubs, regional science, innovation and informatization hubs, innovation and technology clusters, consulting companies, venture funds in Ukraine. Science parks have become the most effective in performing science and technical innovations [12]. Now there is a legal basis for 16 science parks in Ukraine [13], including 8 ones that actually function. There has been 116 innovative projects implemented, 3551 new jobs created and $12.3 \mathrm{bln} \boldsymbol{z}$ worth of products sold (including 1.7 exported), $0.9 \mathrm{bln} z$ transferred to the state budget. State support of innovation projects has been 0.48 bln. $z$ [14]. For instance, one of the most well-known science parks in Ukraine is "E.O.Paton Electric Welding Institute" science park. The science park has implemented 19 innovative projects, within 
which under special regime 6.542 bln. $₹$ worth of innovative products was produced, 1762 new jobs were created, 0.679 bln. $₹$ was transferred to the budget [15]. In 2016 the Institute has got state budget funds to develop the project "Creating experimental model of innovative welding equipment for plastic pipelines construction". Nevertheless, in spite of some successful innovation projects activity of science parks does not make significant impact on economic growth of Ukraine. It is one of 32 innovation projects, financed with the state budget funds by The National Academy of Sciences of Ukraine according to the results of the national contest of innovation projects [16]. Therefore, literature review leads to the idea that innovation do has an impact on economic growth but the level of the relationship between innovation and economic development of different counties vary.

The aim of the article is to analyze the correlation between GDP growth dynamics and innovation variables and to determine innovation factors affecting GDP growth dynamics the most.

Findings. The focus of the research is the relationship between GDP dynamics and innovation factors. Person's coefficient was calculated for each pair of variables (growth vs. innovation factor of growth). Pairwise correlations of the variables were estimated.

Data was collected from Knoema, World data atlas [17] and according to IMF Balance of Payments Manual, 6th edition [18]. Since economic growth can be defined as the increase in the Gross Domestic Product of the country GDP per capita growth (annual \%) states for economic growth. The following innovation factors supposed to affect economic growth were selected:

- Communications, computer, etc. (\% of service exports, weighted average) (CCS). Communications, computer, information, and other services cover international telecommunications; computer data; news-related service transactions between residents and nonresidents; construction services; royalties and license fees; miscellaneous business, professional, and technical services; personal, cultural, and recreational services; manufacturing services on physical inputs owned by others; and maintenance and repair services and government services not included elsewhere;

- Renewable electricity output (REO) (\% of total electricity output). Renewable electricity is the share of electricity generated by renewable power plants in total electricity;

- Renewable energy consumption (REC) (\% of total final energy consumption).

- Information and communication technology (ICT) goods exports (\% of total goods exports) (ICTGE). Information and communication technology goods exports include telecommunications, audio and video, computer and related equipment; electronic components; and other information and communication technology goods. Software is excluded.

- ICT goods imports (\% total goods imports) (ICTGI).

- ICT service exports (\% of service exports) (ICTSE). Information and communication technology service exports include computer and communications services (telecommunications and postal and courier services) and information services (computer data and news-related service transactions);

- High-technology exports (HTE) (\% of manufactured exports). High-technology exports are products with high R\&D intensity, such as in aerospace, computers, pharmaceuticals, scientific instruments, and electrical machinery.

- Patent applications, nonresidents (PAN). Patent applications are worldwide patent applications filed through the Patent Cooperation Treaty procedure or with a national patent office for exclusive rights for an invention--a product or process that provides a new way of doing something or offers a new technical solution to a problem. A patent provides protection for the invention to the owner of the patent for a limited period, generally 20 years.

- Patent applications, residents (PAR).

- Research and development expenditure (\% of GDP) (R\&DE). Expenditures for research and development are current and capital expenditures (both public and private) on creative work undertaken systematically to increase knowledge, including knowledge of humanity, culture, and society, and the 
use of knowledge for new applications. R\&D covers basic research, applied research, and experimental development.

- Trademark applications, direct nonresident (TAN). Trademark applications filed are applications to register a trademark with a national or regional Intellectual Property (IP) office. A trademark is a distinctive sign, which identifies certain goods or services as those produced or provided by a specific person or enterprise. A trademark provides protection to the owner of the mark by ensuring the exclusive right to use it to identify goods or services, or to authorize another to use it in return for payment. The period of protection varies, but a trademark can be renewed indefinitely beyond the time limit on payment of additional fees. Direct nonresident trademark applications are those filed by applicants from abroad directly at a given national IP office.

- Trademark applications, direct resident (TAR).

- Trademark applications, total (TAT).

When studying innovation determinants affecting GDP dynamics data of the following 30 countries was used to calculate correlation coefficients: Australia (AU), Austria (AT), Belgium (BE), Canada (CA), Czech Republic (CZ), China (CN), Denmark (DK), Estonia (EE), Hungary (HU), Germany (DE), Finland (FI), France (FR), Iceland (IC), Italy (IT), Latvia (LV), Luxembourg (LU), Netherlands (NL), New Zealand (NZ), Norway (NO), Poland (PL), Portugal (PT), Slovakia(SK), South Africa (ZA), South Korea (KR), Spain (ES), Sweden (SE), Switzerland (CH), Ukraine (UA), United Kingdom (GB), USA (US). Calculations were performed by the author. Data was analyzed for the following period: 2000-2014. The following data sets were missing and therefore not analyzed (in the tables 1-3 the missing data were marked with the symbol "-"):

- communications, computer, etc. of Denmark, Finland, Latvia, Slovakia, Spain;

- ICT goods exports and imports, patent applications of Italy;

- ICT service exports of Denmark, Finland, Iceland, Slovakia, Spain;

- research and development expenditure of Australia, Iceland, New Zealand;

- trademark applications, direct resident, nonresident and total of Luxembourg, Netherlands.

The findings provide evidence that the relationship between GDP dynamics and selected variables varies significantly across the countries. Table 1 presents estimation results of the correlation between GDP per capita growth (annual \%) and innovation variables in EU-countries (except post-socialists countries).

Table 1 - Correlation coefficient of GDP per capita growth (annual \%) and innovation variables in

EU countries (except post-socialist countries), (developed by the author on the basis of [17])

\begin{tabular}{|c|c|c|c|c|c|c|c|c|c|c|c|c|c|}
\hline \multirow{2}{*}{$\begin{array}{l}\text { Innov. } \\
\text { variable }\end{array}$} & \multicolumn{13}{|c|}{ Pearson's coefficient of GDP growth and innovation variable } \\
\hline & AT & $\mathrm{BE}$ & DK & $\mathrm{DE}$ & ES & $\mathrm{FI}$ & FR & GB & IT & LU & $\mathrm{NL}$ & PT & SE \\
\hline CCS & -0.17 & -0.46 & - & -0.08 & - & - & -0.63 & -0.07 & -0.37 & -0.60 & -0.15 & -0.50 & -0.33 \\
\hline REO & -0.34 & -0.49 & -0.23 & 0.18 & -0.75 & -0.30 & -0.40 & -0.56 & -0.50 & -0.34 & -0.35 & -0.41 & -0.48 \\
\hline REC & -0.49 & -0.45 & -0.16 & 0.14 & -0.69 & -0.18 & -0.21 & -0.47 & -0.44 & -0.41 & -0.32 & -0.29 & -0.55 \\
\hline ICTGE & 0.34 & 0.40 & 0.29 & 0.00 & 0.76 & 0.44 & 0.51 & 0.65 & - & 0.40 & 0.55 & 0.53 & 0.53 \\
\hline ICTGI & 0.13 & 0.31 & 0.36 & -0.03 & 0.62 & 0.44 & 0.50 & 0.76 & - & 0.40 & 0.53 & 0.52 & 0.52 \\
\hline ICTSE & -0.15 & -0.50 & - & 0.07 & - & - & -0.13 & -0.34 & -0.22 & -0.71 & -0.22 & -0.57 & -0.40 \\
\hline HTE & 0.12 & -0.56 & 0.17 & -0.04 & 0.00 & 0.46 & 0.03 & 0.60 & 0.41 & 0.32 & 0.43 & 0.47 & 0.47 \\
\hline PAN & 0.10 & -0.06 & 0.17 & 0.30 & 0.85 & 0.56 & 0.51 & 0.70 & - & -0.47 & 0.41 & 0.21 & 0.14 \\
\hline PAR & 0.17 & -0.68 & 0.27 & 0.02 & -0.66 & 0.35 & 0.08 & 0.61 & - & 0.32 & -0.40 & -0.67 & 0.25 \\
\hline R\&DE & -0.32 & -0.47 & -0.61 & -0.02 & -0.72 & -0.58 & -0.47 & -0.29 & -0.66 & 0.07 & -0.04 & -0.47 & -0.23 \\
\hline TAN & 0.23 & 0.48 & 0.34 & 0.01 & 0.82 & 0.49 & 0.52 & 0.63 & 0.62 & - & - & 0.57 & 0.39 \\
\hline TAR & 0.34 & 0.40 & 0.46 & 0.26 & 0.91 & -0.17 & 0.12 & -0.20 & & - & - & -0.30 & -0.24 \\
\hline TAT & 0.27 & 0.49 & 0.40 & 0.23 & 0.90 & 0.52 & 0.29 & 0.36 & 0.03 & -0.12 & - & 0.12 & 0.24 \\
\hline
\end{tabular}


The highest level of correlation was indicated between the GDP dynamics and the following innovation variables: trademark applications, patent applications, and R\&D expenditures. Spain and United Kingdom proved to be the most innovative countries. The Spanish leadership is obvious the most in case of correlation between GDP dynamics and trademark and patent applications filed by nonresidents. The data of the table show that R\&D expenditures in developed EU-countries were not the key factor of their economic growth during the period.

In the table 2 the correlation coefficients of GDP dynamics and innovation variables in non-EU developed countries.

Table 2 - Correlation coefficient of GDP per capita growth (annual \%) and innovation variables in non-EU developed countries, (developed by the author on the basis of [17])

\begin{tabular}{|c|c|c|c|c|c|c|c|c|c|c|}
\hline \multirow{2}{*}{$\begin{array}{c}\text { Innovation } \\
\text { variable }\end{array}$} & \multicolumn{9}{|c|}{ Pearson's coefficient of GDP growth and innovation variable } \\
\cline { 2 - 12 } & $\mathrm{AU}$ & $\mathrm{CA}$ & $\mathrm{CH}$ & $\mathrm{CN}$ & $\mathrm{IC}$ & $\mathrm{KR}$ & $\mathrm{NO}$ & $\mathrm{NZ}$ & US & ZA \\
\hline CCS & 0.16 & -0.69 & -0.51 & -0.63 & 0.14 & -0.52 & -0.44 & -0.50 & -0.45 & -0.54 \\
\hline REO & 0.12 & -0.33 & -0.51 & -0.39 & -0.58 & -0.50 & 0.23 & -0.13 & - & -0.01 \\
\hline REC & 0.04 & -0.35 & -0.38 & -0.53 & -0.52 & 0.06 & 0.64 & -0.04 & -0.31 & 0.00 \\
\hline ICTGE & 0.36 & 0.41 & 0.49 & 0.64 & 0.55 & 0.53 & -0.30 & 0.50 & -0.13 & 0.30 \\
\hline ICTGI & 0.32 & 0.47 & 0.43 & 0.67 & 0.83 & 0.55 & 0.57 & 0.49 & 0.42 & 0.50 \\
\hline ICTSE & -0.04 & -0.50 & -0.26 & 0.03 & - & 0.60 & -0.46 & -0.45 & 0.28 & -0.53 \\
\hline HTE & 0.14 & -0.11 & -0.83 & 0.59 & 0.58 & 0.62 & 0.26 & 0.66 & 0.34 & 0.50 \\
\hline PAN & -0.07 & 0.12 & -0.23 & 0.32 & 0.25 & -0.34 & 0.44 & 0.55 & -0.34 & 0.27 \\
\hline PAR & 0.07 & -0.20 & 0.31 & -0.14 & -0.19 & -0.51 & -0.30 & 0.52 & -0.26 & 0.46 \\
\hline R\&DE & - & -0.02 & 0.15 & 0.08 & - & -0.51 & -0.69 & - & -0.63 & 0.36 \\
\hline TAN & -0.09 & 0.09 & -0.52 & 0.15 & 0.54 & -0.36 & 0.08 & 0.42 & -0.17 & 0.17 \\
\hline TAR & -0.15 & 0.27 & -0.14 & -0.02 & 0.79 & -0.46 & -0.62 & 0.31 & 0.04 & 0.10 \\
\hline TAT & -0.13 & 0.17 & -0.83 & -0.01 & 0.65 & -0.47 & -0.04 & 0.47 & 0.00 & 0.16 \\
\hline
\end{tabular}

The findings show that in this group of countries the most significant relationship was observed between GDP dynamics and high-technology export. Thus, high-technology export plays the most significant role for South Korea and New Zealand. Strong relationship and negative correlation of these variables in case of Switzerland shows that GDP of the country is not related to high-technology export. Moreover, the bigger GDP growth - the less role of high-tech export in economic development of the country. Within the group of non-EU developed countries innovations play the most important role in GDP growth of China and Iceland. It is obvious that in this group of countries the most significant positive correlation between GDP dynamics and trade mark applications takes place in Iceland. This country is the leader according to the results of the study of the relationship between GDP and ICT goods import (0.83), that contribute to the technical upgrade of Iceland producing facilities.

Data of the table prove the well-known fact concerning the role of export for fast-growing Chinese economy. It is obvious that its GDP dynamics is related not only to high-tech export but also to the widespread use of ICT goods from abroad, that essentially contribute to implementation of foreign technologies in China.

In the table 3 there are correlation coefficients of GDP growth per capita and innovation variables, calculated for post-socialist European countries. In this group of countries relationship between GDP dynamics and trademark applications, ICT goods export and import is present. The most significant level of correlation between GDP and innovation variables was revealed in Check Republic, Estonia and Hungary. Check Republic and Hungary lead in the category of correlation between GDP and trademark applications, and Estonia uses ICT export and import, that essentially contribute to the upgrade of its producing facilities. 
В.Я. Голюк. Вплив інновацій на динаміку ВВП держави

Table 3 - Correlation coefficient of GDP per capita growth (annual \%) and innovation variables in post-socialist countries, (developed by the author on the basis of [17])

\begin{tabular}{|c|c|c|c|c|c|c|c|}
\hline \multirow{2}{*}{ Innovation variable } & \multicolumn{7}{|c|}{ Pearson's coefficient of GDP growth and innovation variable } \\
\cline { 2 - 8 } & UA & CZ & EE & HU & LV & PL & SK \\
\hline CCS & $-0,8$ & -0.03 & -0.56 & -0.10 & - & 0.14 & - \\
\hline REO & -0.79 & -0.56 & -0.45 & -0.67 & -0.51 & -0.29 & -0.28 \\
\hline REC & -0.38 & -0.55 & -0.28 & -0.70 & 0.05 & -0.19 & -0.29 \\
\hline ICTGE & 0.05 & -0.41 & 0.62 & 0.15 & -0.65 & -0.15 & -0.22 \\
\hline ICTGI & 0.35 & -0.49 & 0.70 & -0.02 & 0.15 & -0.26 & -0.22 \\
\hline ICTSE & -0.76 & -0.41 & -0.55 & -0.64 & - & -0.06 & - \\
\hline HTE & 0.06 & -0.41 & 0.53 & 0.36 & -0.45 & -0.24 & -0.03 \\
\hline PAN & -0.37 & 0.15 & 0.29 & 0.54 & 0.49 & -0.18 & -0.09 \\
\hline PAR & 0.32 & -0.58 & -0.65 & 0.28 & -0.85 & -0.22 & 0.19 \\
\hline R\&DE & 0.46 & -0.46 & -0.22 & -0.63 & 0.00 & -0.34 & -0.34 \\
\hline TAN & -0.34 & 0.47 & 0.45 & 0.63 & 0.55 & -0.12 & 0.18 \\
\hline TAR & -0.24 & 0.76 & -0.05 & 0.63 & 0.22 & 0.73 & 0.69 \\
\hline TAT & -0.28 & 0.62 & 0.44 & 0.64 & 0.58 & 0.02 & 0.27 \\
\hline
\end{tabular}

The findings are consistent with the previous research. ICT goods imports states in this research for the transfer of technologies, also studied by Roman Gurbiel [7]. The findings provide evidence of positive relationship between GDP growth and ICT goods imports that leads to the assumption that the implementation of innovation technologies contributes economic growth. However, the correlation could also mean that high GDP growth rate gives the countries the financial possibility to increase expensive import of high-technology goods. Causal relationship between these variables needs additional tests. Within the post-socialist group the negative sign of correlation of these variables happens (in Check Republic, Poland and Spain), however the level of the relationship in these cases is not high.

The findings confirmed the research results of Changtao Wang [10], who used patent and trademark statistics as innovation proxies to examine the influence of innovations on economic growth. The magnitude and sigh of correlation coefficient vary significantly across the countries. While trademark applications correlate with GDP growth dynamics mostly positive (except Austria, Switzerland, Italy, Korea, Luxemburg, Norway and Ukraine), correlation of patent applied by nonresidents and GDP is mostly positive, and correlation of patent applied by residents and GDP varies across the countries. However, in EU-countries correlation is mostly positive, while non-European counties have mostly negative correlation of these variables.

Analyzing the association between GDP growth dynamics and export of communications, computer and other service it should be admitted that positive sign of correlation is observed only in Korean economy. In other countries, correlation is negative that means low (if any) role of communications, computer and other services in economic growth of these countries. Role of innovations in electricity production and energy consumption (presented in the research by renewable electricity output and renewable energy consumption) is limited. Only in Norway, correlation between GDP growth and these variables is positive and is equal to 0.64.

The results of the study show that there is the negative association between GDP dynamics and research and development (R\&D) expenditures of developed countries. It leads us to the assumption that in the period 2000-2014 R\&D expenditures were not the key driver of economic growth in these countries. Positive (but not high) correlation between these variables takes place only in New Zealand.

Analyzing the relationship between GDP growth dynamics and innovation variables in Ukraine rather weak association of innovation factors and economic development can be observed in most cases. The findings provide evidence that strong negative association takes place in case of relationship between GDP growth dynamics and communications, computer, etc. (\% of service exports), renewable energy consumption (\% of total energy consumption). Thus, in 2015 the fraction of communication, computer and information services in the total amount of services of Ukraine was $16.3 \%$, while the majority of Ukrainian 
services was performed by its transport facilities (54\% of the total amount of export services) [11].

Correlation coefficients that show the relationship between GDP and high-tech export is close to zero, that confirms raw orientation of Ukrainian export. The level of correlation between ICT goods import and GDP dynamics is positive but not high. Thus in 2015 the fraction of electrical equipment in the total amount of goods import of Ukraine was $16.7 \%$, the fraction of means of transport $-4.6 \%$. The fraction of electrical equipment in the total amount of goods export of was $10.3 \%$, and the fraction of means of transport $-1.8 \%$ [11]. Comparing to 2014 there is a decline in both export and import of these goods. Ferrous metallurgy crops remain the main parts of Ukrainian export and the main part of Ukrainian import are oil and oil products [11].

Patent and trademark applications data also show their weak impact on economic growth of Ukraine. Statistical data show that the number of patent applications has been declining over the past couple of years. Thus, 4497 applications was filed to the State intellectual property service of Ukraine in 2015, that was $6.6 \%$ less than in 2014 and 17\% less than in 2013 [19]. Positive (but not high) correlation between R\&D expenditures and GDP growth in Ukraine theoretically could mean impact of the expenditures on economic development, but also it could mean additional funds available in the period of economic growth. Causal relationship between these variables needs additional tests, for instance using Granger tests.

That leads us to the conclusion concerning low impact of innovations on economic development of Ukraine that is consistent with the studies mentioned above. Analysis of the technologically advanced countries' experience lets us to suggest the following measures of innovation policy to be taken by Ukrainian authorities to drive economic growth:

- designing and implementing institutional changes to support technical learning and innovation;

- government support to private sector R\&D including R\&D subsidies and R\&D tax incentives;

- encouraging information and technology communication;

- government support to the knowledge-based industries and services;

- state promotion of innovation and technology transfer from scientific to industrial sector of Ukrainian economy;

- import of modern technologies, foreign direct investment promotion;

- improvement of foreign technologies using national R\&D capabilities;

- effective intellectual property protection.

Conclusions and further research directions. Many studies on the impact of innovations on GDP dynamics show that level of the relationship between innovations and economic development of different counties vary. In general, the findings of the study are consistent with the previous research. The study has showed that the strength and the sign of the association of innovation variables with GDP growth vary across the countries. The highest level of correlation has been indicated between the GDP dynamics and the following innovation variables: trademark applications, patent applications, hightechnology exports and ICT goods imports.

Among the variety of indices that can be used as proxies for innovations, the special place belongs to patents and trademark applications. While the association of these variables and GDP is rather strong in most cases, the sign of correlation varies.

The results of the study show that there is the negative association between GDP growth and R\&D expenditures of developed countries. Analyzing the relationship between GDP growth dynamics and innovation variables in Ukraine rather weak association of innovations and economic development can be observed in most cases. Certain measures to be taken by Ukrainian authorities to drive innovations and economic growth were suggested.

Novelty of the paper lies in the following:

- analysis of correlation between innovations and GDP dynamics in 30 countries of different level of development is the sequel of the previous studies focused on the relationship between innovations and economic growth; 
- negative association between GDP dynamics and R\&D expenditures of developed countries was revealed that leads to the assumption that in the period 2000-2014 R\&D expenditures were not the key driver of economic growth in these countries;

- on the basis of technologically advanced countries' experience certain measures of innovation policy to be taken by Ukrainian authorities to drive economic growth were suggested.

The following research will be concerned the relationship between GDP growth dynamics and innovation factors using the Granger test to reveal causal relationship between the variables.

1. Czarnitzki D. Innovation policy and economic growth [Electronic resource]/ D. Czarnitzki, O. Toivanen // Economic papers. 2013. - №482. - Access mode: $h$ ttp://ec.europa.euleconomy_finance/publications/ economic_paper/2013/pdf/ecp482_en.pdf.

2. Федулова Л. Концептуальна модель інноваційної стратегії України / Л. Федулова // Економіка і прогнозування. 2012. - № 1. - С. 87-100

3. Стреліна О.М. Інноваційний розвиток економіки України: проблеми та перспективи / О. М. Стреліна // Ефективна економіка. - 2013. - №7.

4. Gregersen B. How do innovations affect economic growth? Some different approaches in economics [Electronic resource] / B. Gregersen, B. Johnson // Innovation systems and European integration (ISE): European Commission research project. - EU Commission, 1997. - Access mode: http://citeseerx.ist.psu.edu/viewdoc/download?doi=10.1.1.198.4088\&rep=rep1\&type=pdf.

5. Rosenberg N. Innovation and economic growth [Electronic resource]/ N. Rosenberg. - OECD, 2004. - Access mode: https://www.oecd.org/cfe/tourism/34267902.pdf.

6. Геєць В.М. Інноваційні перспективи України / В.М. Геєць, В.П. Семиноженко. - Харків: Константа, 2006. - 272 с.

7. Gurbiel R. Impact of innovation and technology transfer on economic growth: the Central and Eastern Europe experience [Electronic resource] / R. Gurbiel // Warsaw School of Economics Center of International Production Cooperation. - Warsaw, 2002. - Access mode: http://www.eadi.org/typo3/fileadmin/WG_Documents/Reg_WG/gurbiel.pdf.

8. Ілляшенко С.М. Проблеми і перспективи ринково-орієнтованого управління інноваційним розвитком: монографія / за ред. д.е.н. С.М. Ілляшенка. - Суми: ТОВ «Друкарський дім «Папірус», 2011. -644с.

9. Gerguri S.The impact of innovation into the economic growth [Electronic resource]/ S. Gerguri, V. Ramadani // MPRA Paper. - $2010 . \quad$ - $\quad$ № 22270. - $\quad$ Access mode: https://mpra.ub.unimuenchen.de/22270/1/The_impact_of_innovation_into_economic_growth-final_2008-eng-Shqipe-Veland.pdf.

10. Wang Ch. The long-run effect of innovation on economic growth [Electronic resource]/ Ch. Wang. - Australia: School of Economics, 2013. - Access mode: http://www.murdoch.edu.au/School-of-Business-and-Governancel_document/AustralianConference-of-Economists/The-long-run-effect-of-innovation-on-economic-growth.pdf.

11. Зовнішня торгівля України товарами та послугами у 2015 році: статистичний збірник. - К.: Державна служба статистики України, 2016. - 156с.

12. Геєць В.М. Інноваційна Україна 2020: національна доповідь / за заг. ред. В.М. Гейця, А.І. Даниленка, Е.М. Лібанової та ін. - К., 2015. - 336 с.

13. Закон України «Про спеціальний режим інноваційної діяльності технологічних парків» [Електронний ресурс]. Режим доступу: http://zakon4.rada.gov.ua/laws/show/991-14

14. Технологічні парки України [Електронний ресурс] / Сайт Державного агентства з питань електронного урядування України. - Режим доступу: http:/old.dknii.gov.ua/?q=node/1065

15. Технологический парк «Институт электросварки им. Е.О. Патона» [Электронный ресурс] / Сайт Института электросварки им. Е.О. Патона. - Режим доступу: http://paton.kiev.ua/ru/o-nas/ntk-ies/innovacionnoe

16. Розпорядження президії НАН України «Про затвердження переліку науково-технічних проектів НАН України, які будуть реалізовуватися у 2016 році» [Електронний ресурс]. - Режим доступу: http://www1.nas.gov.ua/innovations/news/Documents/160331_197.pdf

17. World development indicators, World Data Atlas, Knoema [Electronic resource]. - Access mode: http://knoema.ru/WBWDIGDF20160ct/world-development-indicators-wdi-quarterly-update.

18. Balance of payments and international investment position manual, 6-th edition (2009). Washington, D.C.: International Monetary Fund [Electronic resource]. - Access mode: https://www.imf.org/external/pubs/ft/bop/2007/pdf//ppm6.pdf

19. Річний звіт за 2015 рік [Електронний ресурс]. - К.: Державна служба інтелектуальної власності України, 2016. -Режим доступу: http://sips.gov.uali_upload/file/zvit_2015_ua.pdf

1. Czarnitzki D. \& Toivanen O. (2013) Innovation policy and economic growth. Economic papers, 482. Retrieved from: http://ec.europa.eu/economy_finance/publications/economic_paper/2013/pdf/ecp482_en.pdf.

2. Fedulova L. (2012) Konceptual'ni model' innovacijnoyi strategiyi Ukrayiny'[Conceptual model of innovation strategy of Ukraine]. Ekonomika i prognozuvannya [Economics and focasting], 1, 87-100 [in Ukrainian].

3. Strelina O.M. (2013) Innovacijny'j rozvy'tok ekonomiky' Ukrayiny': problemy' ta perspekty'vy' [Innovative development of Ukraine]. Efekty'vna ekonomika [Effective economy], 7 [in Ukrainian].

4. Gregersen B. \& Johnson B. (1997) How do innovations affect economic growth? Some different approaches in 
economics. Innovation systems and European integration (ISE): European Commission research project. Retrieved from: http://citeseerx.ist.psu.edu/viewdoc/download?doi=10.1.1.198.4088\&rep=rep1\&type=pdf.

5. Rosenberg N. (2004) Innovation and economic growth. OECD. Retrieved from: https://www.oecd.org/cfe/tourism/34267902.pdf.

6. Geyecz' V.M. \& Semy`nozhenko V.P. (2006) Innovacijni perspekty'vy` Ukrayiny' [Innovative prospective of Ukraine]. Xarkiv: Konstanta [in Ukrainian].

7. Gurbiel R. (2002) Impact of innovation and technology transfer on economic growth: the Central and Eastern Europe experience. Warsaw. Retrieved from: http://www.eadi.org/typo3/fileadmin/WG_Documents/ Reg_WG/gurbiel.pdf.

8. Illyashenko S.M. (Eds) (2011) Problemy' i perspekty 'vy' ry 'nkovo-oriyentovanogo upravlinnya innovacijny 'm rozvy 'tkom [Problems and prospective of market-oriented management of innovative developement]. Sumy”: TOV «Drukars`ky j dim «Papirus» [in Ukrainian].

9. Gerguri S. \& Ramadani V. (2010) The impact of innovation into the economic growth. MPRA Paper, 22270. Retrieved from: https://mpra.ub.uni-muenchen.de/22270/1/The_impact_of_innovation_into_economic_growth-final_2008-eng-ShqipeVeland.pdf.

10. Wang Ch. (2013) The long-run effect of innovation on economic growth. Australia: School of Economics. Retrieved from: http://www.murdoch.edu.au/School-of-Business-and-Governance/_document/Australian-Conference-of-Economists/The-long-runeffect-of-innovation-on-economic-growth.pdf.

11. Zovnishnya torgivlya Ukrayiny tovaramy ta poslugamy u 2015 roci [Foreign trade of goods and services of Ukraine in 2015] (2016). Kyiv. Retrieved from: http://www.ukrstat.gov.ua/druk/publicat/kat_u/publ10_u.htm [in Ukrainian].

12. Geyecz' V.M. (Eds) (2015) Innovacijna Ukrayina 2020: nacional'na dopovid' [Innovative Ukraine 2020: national report] Kyiv. [in Ukrainian].

13. Zakon Ukrayiny` «Pro special'ny`j rezhy`m innovacijnoyi diyal'nosti texnologichny`x parkiv» [The Law of Ukraine "On the special mode of the science parks' activity"]. (n.d.). zakon.rada.gov.ua. Retrieved from: http://zakon4.rada.gov.ua/laws/show/99114 [in Ukrainian].

14. Sait Derzhavnogo agentstva z py`tan` elektronnogo uryaduvannya Ukrayiny'. [Site of State agency of electronic management of Ukraine]. old.dknii.gov.ua. Retrieved from: http://old.dknii.gov.ua/?q=node/1065 [in Ukrainian].

15. Sait Institutu elektrozvaryuvannya im. Ye.O. Patona [Site of Ye. O. Paton Institute of electric welding]. paton.kiev.ua. Retrieved from: http://paton.kiev.ua/ru/o-nas/ntk-ies/innovacionnoe [in Russian].

16. Rozporyadzhennya prezy'diyi NAN Ukrayiny” "Pro zatverdzhennya pereliku naukovo-texnichny`x proektiv NAN Ukrayiny", yaki budut realizovuvaty"sya u 2016 rocis [The order of Presidium of The National Academy of Science of Ukraine "On the adoption of the science and technical projects list of NAS of Ukraine, that will be performed in 2016"] Retrieved from: http://www1.nas.gov.ua/innovations/news/Documents/160331_197.pdf [in Ukrainian].

17. World development indicators (2016). World Data Atlas. Knoema. Retrieved from: http://knoema.ru/WBWDIGDF20160ct/world-development-indicators-wdi-quarterly-update.

18. Balance of payments and international investment position manual, 6-th edition (2009). Washington, D.C.: International Monetary Fund. Retrieved from: https://www.imf.org/external/pubs/ft/bop/2007/pdf/bpm6.pdf.

19. Richny”j zvit za 2015 rik [Annual report for 2015] (2016). Kyiv. Retrieved from: http://sips.gov.ua/i_upload/file/zvit_2015_ua.pdf [in Ukrainian].

В.Я. Голюк, к.е.н. доцент кафедри менеджменту НтуУ «Київський політехнічний інститут імені Ігоря Сікорського», (м. Київ, Україна)

Вплив інновацій на динаміку ВВП

Метою дослідження $є$ аналіз впливу інновацій на динаміку ВВП 30 країн різного рівня розвитку. Найвищий рівень кореляції було відзначено між динамікою ВВП та наступними інноваційними змінними: заявки на отримання патентів та реєстрацію торгових марок, високо-технологічний експорт, імпорт високотехнологічної продукції та споживання відновлюваної енергії. Аналізуючи зв'язок між динамікою зростання ВВП та інноваційними змінними в Україні слід відмітити, що у більшості випадків спостерігається досить низький рівень зв'язку економічного розвитку та інновацій.

Ключові слова: вплив, кореляція, зв'язок, динаміка ВВП, економічне зростання, інновація.

В.Я. Голюк, к.э.н. доцент кафедры менеджмента НТуУ «Киевский политехнический институт имени Игоря Сикорского» (г. Киев, Украина.)

Влияние инноваций на динамику ВВП

Целью исследования является анализ влияния инноваций динамику ВВП 30 стран различного уровня развития. Наиболее высокий уровень корреляции был отмечен между динамикой ВВП и последующими инновационными переменными: заявки на получение патентов и регистрации торговых марок, высокотехнологический экспорт, импорт высокотехнологичной продукции и потребление возобновляемой энергии. Анализируя связь между динамикой роста ВВП и инновационными переменными в Украине, следует отметить, что в большинстве случаев наблюдается достаточно низкий уровень связи экономического развития и инноваций.

Ключевые слова: влияние, корреляция, связь, динамика ВВП, экономический рост, инновация.

Отримано 31.10.2016 p. 